\title{
Parenthesis as a resource in the grammar of conversation
}

\author{
Outi Duvallon \\ Institut national des langues et civilisations orientales, Paris \\ Sara Routarinne \\ University of Helsinki
}

\begin{abstract}
This article investigates how speakers in talk-in-interaction utilize parenthesis in order to organize information in turns, as well as to manage local interactive tasks and shape the participant framework. By parenthesis we mean constructions which temporarily suspend the progression of another syntactic construction or wider action sequence. Parentheses provide interesting challenges for practitioners of interactional linguistics. In conversation, using parentheses enables participants to embed several turn constructional units and even speaker change within a single syntactic unit. This paper focuses on interfaces between the frame construction and parenthesis. We first discuss syntactic, prosodic and sequential/textual projection as means of indicating non-completion and suspension of the current turn constructional unit. We also investigate how parentheses relate to the trajectory of the main line of conversation. The aim is to show that parentheses are an important resource contributing to the coherence of the conversation's contents and actions. The paper combines two approaches, conversation analysis and a syntactic approach to spoken language. This double perspective allows us to articulate differences between parentheses and self repairs which also interrupt evolving turn constructional unit. The analyses are based on Finnish conversational data.
\end{abstract}

\section{$1 \quad$ Introduction}

\subsection{Parenthesis in conversation}

One of the starting points of ethnomethodological conversation analysis is that language and its structures have developed to be appropriate and functional to serve the participants' interactive goals (see Schegloff 1979, 1996, Hakulinen 1993, Couper-Kuhlen and Selting 2001). When you begin to analyze how smaller linguistic units form larger sequences in a conversation, for example how a narrative is constructed in an interaction, you sooner or later find hitches where the parts no longer follow one another seamlessly. Although many segments of talk can seem incoherent when viewed only in their immediate context, a systematic analysis of the architecture of conversation brings to light phenomena which are highly regular. These hitches provide the researcher with a unique vantage point to examine how structures are produced and recognized in the course of a conversation (cf. Selting 2001). 
In this paper, we would like to highlight a phenomenon which has been called parenthesis. One such parenthesis is shown in bold face in example 1, which has been drawn from Finnish conversational data: ${ }^{1}$

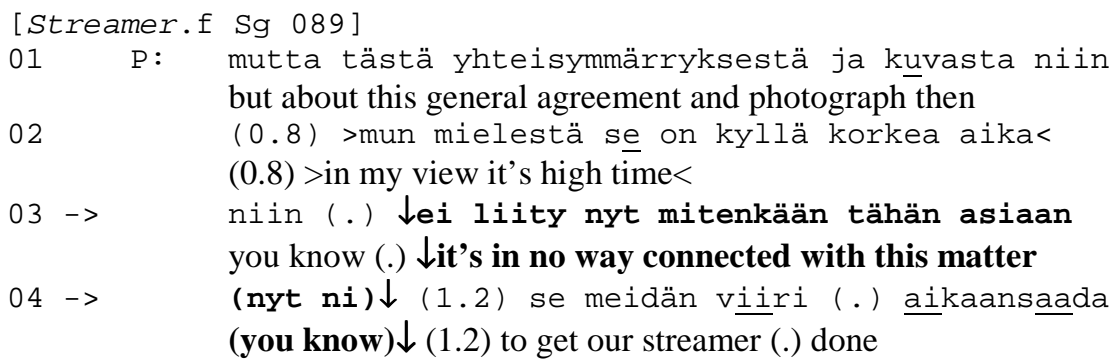

A certain segment of talk can be recognized as parenthetical only in relation to its environment. Essential in this contextual relationship is to distinguish a frame construction which is higher in the textual hierarchy (see lines 2-4: 'in my view it's high time you know - - to get our streamer done') as well as a syntactically independent parenthetical segment which is embedded within this structure and is hierarchically subordinated to it (lines 3-4: 'it's in no way connected with this matter (you know) ${ }^{2}$ ) (for the terms hierarchically superordinate and hierarchically subordinate see also Auer, this volume).

Observation of a frame construction and an embedded parenthesis is wholly retrospective (cf. Stoltenburg 2002). If we try to view the conditions of the on-line processing, as it were, we can see that when the turn in our example has progressed to ei liity nyt mitenkään tähän asiaan (nyt ni) 'it's in no way connected with this matter (you know)' (lines 3-4) the recipient naturally does not yet know what exactly will be said next. Nevertheless, as

\footnotetext{
${ }^{1}$ This article is based on empirical language examples from Finnish which have been selected from audiotaped conversation databases. The samples we cite come from the conversation material archives of the University of Helsinki Department of Finnish (signum "Sg") and from Routarinne's personal collection. All conversations have been taped in authentic settings. Conversations are either face-to-face (name of material followed by "f") or telephone conversations (indicated with a "t"). Each example cited has its own nickname, such as example 1 Streamer which is always repeated if the same excerpt is analyzed again. The data have been transcribed according to the conventions of conversation analysis. The key to symbols used in the transcriptions is provided in the appendix. We use bold typeface to highlight the features we are discussing, most often to show the parenthetical sequences in our examples. A free translation is provided on its own line. This article is based on an earlier Finnish-language version (Duvallon and Routarinne 2001). We are especially grateful to Auli Hakulinen and Margret Selting, who gave us valuable comments on the present version, and to Nely Keinänen and Kimmo Absetz, who translated the article.

${ }^{2}$ The parenthesis is uttered in a lower register than its surroundings. This is indicated by downward-pointing arrows. In addition, the sequence has flat intonation. In the transcript there is a lack of underlining which is used to indicate stress.
} 
the unit-in-progress unfolds word by word in real-time the projectability of its course increases. The recipient has probably recognized that the preceding structure (lines 2-3: 'in my view it's high time you know') is incomplete: the expression on korkea aika 'it's high time' has projected a continuation either containing an infinitive verb phrase or a nominal clause introduced by et(tä) 'that'.

On the other hand, we can assume that the participants are also able to orient to changes in the trajectory and to the repairing of what has already been said. The potential for real-time editing and reanalysis is a specific resource of talk-in-interaction (e.g. Goodwin 1979 or Schegloff 1996). When in our example the inserted material does not correspond to expectations but rather breaks the trajectory of the current turn, the horizon of expectations is being reshaped. However, the segment 'it's in no way connected with this matter (you know)' is not conclusively understood as a parenthesis until the recipient recognizes the next part, consisting of an NP and a non-finite verb ('to get our streamer done') as a continuation of the preceding structure.

Parentheses are interesting from the perspective of how information is organized in turns, since they manifest the syntactic, semantic and pragmatic multidimensionality of the text (see also Auer, this volume). Often they have been characterized as asides. However, Mondada and Zay (1999) have pointed out how conversation utilizes parentheses in the development of topics. In fact, insertions form a fertile space for manipulating the topic of conversation. Within them, it is possible to bring up new topics, push old ones aside, or boost the status of the topic already being discussed. Parentheses often provide (background) information which is essential for the progression of the main line of the conversation.

When we approach the way in which texts emerge from talk-ininteraction, we can see that the role of parentheses is not limited to just organizing information in turns-at-talk. The various segments of a narrative require participants to perform different kinds of tasks (cf. Goodwin 1984: 227). Indeed, it is possible to embed, within a syntactically unified frame construction, an entire interactional segment consisting of several independent utterances and containing more than one turn and one speaker (cf. Schegloff 1979: 262-269, Svennevig 1999: 271-272). This observation, and others like it, provide particular challenges for practitioners of interactional linguistics.

\subsection{Research objectives}

As with many other linguistic phenomena, the identification and description of parenthesis are based on a whole cluster of features, though some kind of discontinuity is an essential feature of the phenomenon. We combine two 
approaches in this article, conversational analysis and a syntactic approach we present in section 2 . The syntactic perspective allows us to articulate differences between parentheses and certain kinds of repairs.

In the empirical sections ( 3 and 4 ) we are chiefly interested in the intersection of the superordinate structure and parenthesis. We focus on how parentheses provide a resource for narrative and explicative sequences in the grammar of interaction.

We will first discuss what kinds of information participants need for recognizing that the frame construction is incomplete and has been interrupted (section 3). These factors can be syntactic, prosodic, semantic and pragmatic. Sometimes the parenthetical interpretation can be triggered by even a single factor pointing to the discontinuity. A key feature is grammatical discontinuity. Parentheses differ from grammatical subordination in that they neither complement their frame construction syntactically (i.e. their textually superordinate structure), nor any part of it. Instead, they momentarily suspend the unfolding of a structure or some wider activity pattern (cf. Blanche-Benveniste et al. 1990: 147-150, Mondada and Zay 1999, Hakulinen et al. forthcoming).

In talk, a prosodic hitch or change is one kind of an index of syntactic discontinuity. However, we should regard prosodic characteristics as symptoms of parenthesis rather than as their necessary features, since in spontaneous talk parentheses do not always seem to be similarly prosodically marked (see Mondada and Zay 1999, Blanche-Benveniste 1997: 72-73, 121-123). Prosodic hitches can also lead to other phenomena such as repair.

There is also a discontinuity of content and action between parentheses and the frame construction. Berrendonner (1993) speaks of two separate but embedded discursive programs, each of which has its own relatively independent cognitive objectives and each of which calls for its own, independent planning (see also Mondada and Zay 1999, Zay 1995). Parenthetical inserts can for instance be used to manage the participation framework (cf. C. Goodwin 1984, 1987 and Goodwin and Goodwin 1986).

Our second research objective is to investigate how parenthetical inserts relate to the trajectory of the main line of conversation (section 4). We discuss the semantic relationships between the main line and the parenthesis, the work a parenthesis is doing in an ongoing sequence, its influence on the sequential organization of the conversation and the shaping of the participation framework. If an ongoing conversation is looked at from a holistic perspective, parentheses turn out to be an important resource contributing to the coherence of the conversation's contents and actions.

We may assume that the basic mechanisms for identifying discontinuity are general, although projection of an utterance is based on different kinds 
of linguistic details, depending on the type of language in question. This article is based on Finnish examples only. Finnish is a member of the FinnoUgric family of languages, and one of its typological specialities is an abundance of cases. In Finnish, case endings indicate syntactical relationships: a prototypical subject NP lacks a suffix and is therefore unmarked; a prototypical object NP is marked by an accusative or partitive case ending. Otherwise suffixes indicate syntactic relationships in a way largely similar to how prepositions function in the Indo-European languages (cf. e.g. Holmberg and Nikanne 1993, Helasvuo 2001: 36-64; see the end of the article for an explanation of glosses).

\section{Approach}

2.1 Conversation analysis in the study of parentheses

Conversation analytic research has touched upon parentheses especially in conjunction with studies of insertions and side sequences (Jefferson 1972, Svennevig 1999: 257-315), repair organization (Schegloff 1979, Sorjonen 1997, Auer, this volume), word search (Goodwin and Goodwin 1986, Goodwin 1987), compound turn constructional units (Lerner 1991) and narration (Goodwin 1984, Sorjonen 2001a: 241), but lately also as a phenomenon in its own right (Stoltenburg 2002, Routarinne 2003: 69-160).

When we speak about "frame construction" (cf. Stoltenburg 2002: section 6), we often mean the same as what is called the "turn constructional unit", hereafter TCU (cf. Sacks, Schegloff and Jefferson 1974, Ford and Thompson 1996, Selting 1996). One of the ideas we develop here is that parenthetical inserts enable one to deviate from the basic rule of turn-taking, each speaker being entitled to one constructional unit at a time (see Sacks, Schegloff and Jefferson 1974). An embedded parenthetical sequence does not alter the trajectory of the frame construction but rather halts its progress towards a transition relevance place, TRP (Lerner 1991: 447).

At a higher level than the TCU, each turn in a sequence anticipates, and to an extent also limits, what can be expected to follow it. Also, larger sequential entities can provide a frame within which a parenthesis is inserted when the sequential implications are strong enough to make a certain kind of continuation relevant (Sacks, Schegloff and Jefferson 1974, Heritage 1984: 304-307).

Repair organization is an essential part of the real-time shaping of turns. Although participants seldom explicitly articulate problems in the flow of the conversation, talk produced in real time is continuously edited during the course of the conversation, for instance when problems are encountered in the production or reception of talk. Parentheses share some characteristics with repairs, especially a speaker's self-initiated self-repairs within the same 
(incomplete) turn or TCU (cf. Schegloff, Jefferson and Sacks 1977, Schegloff 1979, Sorjonen 1997). These phenomena delay the progress of the current turn towards a TRP. However, we want to emphasize that parentheses differ from repairs such as replacements and modifications (below examples 2 and 5) both structurally and by the tasks they perform (cf. 2.2).

\subsection{Syntactic analysis}

In our syntactic analyses, we utilize tools for the grammatical approach to spoken language developed by the French research group GARS (Groupe Aixois de Recherches en Syntaxe) (cf. Blanche-Benveniste et al. 1987, 1990, Blanche-Benveniste 1990, 1997). The fundamental idea of this approach is that in the linear flow of talk, successive elements can relate to their environment in at least two different ways. On one hand, they can form syntagmatic units, which are based on dependency relations, notably on a governing element, i.e. a verb, a noun, or an adposition, creating rection slots in its environment. On the other hand, the relationship between two or more elements can be paradigmatic in its organization. In the latter case, the syntagmatic flow of talk is halted, as it were, on some rection slot, upon which more than one realization is produced.

The following extract exemplifies a self-repair segment and its syntactic analysis. In the segment the speaker replaces a colloquial personal pronoun se ('that one') with the standard language personal pronoun hän ('s/he'):

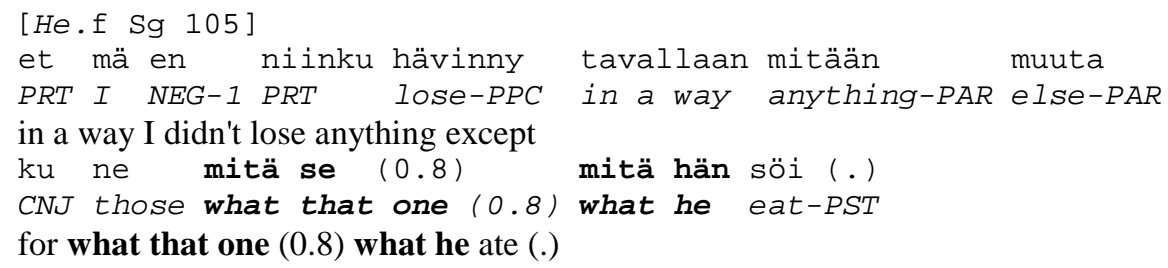

In the grammatical perspective it is crucial that the successive sequences mitä se 'what that one' and mitä hän 'what he' do not form one syntagmatic unit together but are instead both in a similar relationship to other surrounding material. They fill the subject and object argument slots created by the verb syöd $\ddot{a}$ 'eat'. Materials produced in one single rection slot can be presented as paradigmatic lists. The idea of syntagmatic and paradigmatic relations is illustrated below with the horizontal and vertical axes: 
(3)

[He.f Sg 105]

et mä en niinku hävinny tavallaan mitään muuta ku ne mitä

in a way I didn't lose anything except for

what that one

mitä hän söi

what he ate

In this kind of a graphical presentation where material filling the same syntactic position is stacked along the vertical axis, syntagmatic relations and the constructional scheme of the entire construction emerge on the horizontal axis. In each syntactic slot, the vertical column - the paradigmatic dimension - corresponds to realizations produced in talk, but it also symbolizes other possible realizations of the same rection slot. On the level of syntax, there is thus only one of each syntactic slot, whereas in principle each of them has an infinite number of lexical realizations.

In talk, paradigmatic lists are created for example when the speaker is searching for a suitable word. Similarly, we can consider the coordination of two or more elements to be a manifestation of a paradigmatic dimension:

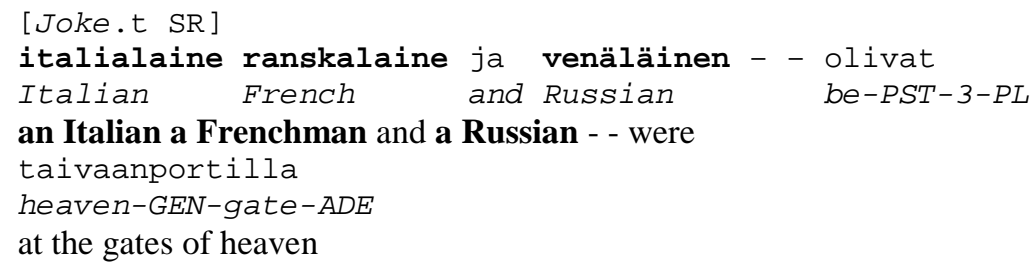

We use these figures for illustrating a robust syntactic analysis, and at the same time, our hypothesis about the editing which participants in a conversation must do while interpreting its structures. In other words, the turn's recipients also identify syntagmatic and paradigmatic relations between elements.

The need for editing becomes even more tangible in example 5 below. In addition to clarifying and modifying previously produced elements of talk, the participants sometimes also anticipate some elements and later place these into their appropriate contexts:

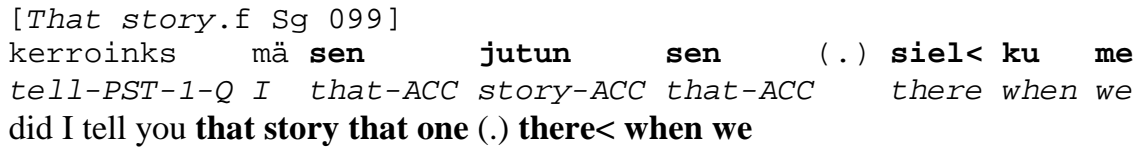




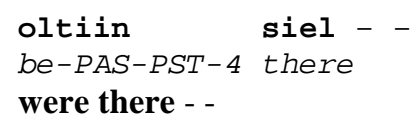

Even during a single verb construction, the speaker might move back and forth several times along the syntagmatic axis of the construction. A structural analysis, based on distinguishing syntagmatic and paradigmatic relationships, first of all exposes the practices by which the speaker explicitly forms the constructions s/he is producing. Secondly, this perspective allows us to see phenomena that on the surface appear widely different - such as repetition, word search, certain types of self-repair as well as the use of parallels and lists - as being based on one single structural resource of language, utilization of its paradigmatic dimension (cf. de Saussure (1983[1916]: 128, Jakobson 1956).

On the other hand, this kind of structural approach brings out differences in areas where other kinds of approaches see similarities. A syntactic feature which can be said to be typical of parenthetical insertions is that they do not syntagmatically complement their frame construction and are also not in a paradigmatic relationship to any part of it:

\begin{tabular}{l} 
(6) [Streamer.f Sg 089] \\
\begin{tabular}{|l|}
\hline $\begin{array}{l}\text { se on kyllä korkea aika niin } \\
\text { it's high time, you know, }\end{array}$ \\
\hline \\
ei liity nyt mitenkään tähän asiaan (nyt ni) \\
to get our streamer done
\end{tabular} \\
it's in no way connected with this matter (you know) \\
\hline
\end{tabular}

The speaker produces another, independent structure within the construction which is underway, and then returns to the frame construction which has been kept waiting. Thus the parenthesis remains outside of both the syntagmatic and the paradigmatic axis, as it were, and therefore differs from the word replacements and construction modifications seen above (examples 2 and 5).

\section{Interfaces between frame construction and parenthesis}

In this section we focus on places where parenthetical inserts interrupt the frame construction. We will discuss syntactic, prosodic and sequential/textual projection as a means of indicating non-completion and 
interruption. We will also consider devices enabling participants to recognize the continuation of the frame construction.

3.1 An unfinished syntactic construction as the context of a parenthesis Parenthesis can sometimes interrupt the frame construction in places which have typically been considered to be syntactically very solidly connected. In example 7, the parenthetical segment (bold typeface) comes between the

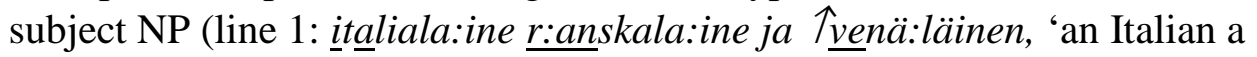
Frenchman and a Russian') and the finite verb (line 6: 'were'):

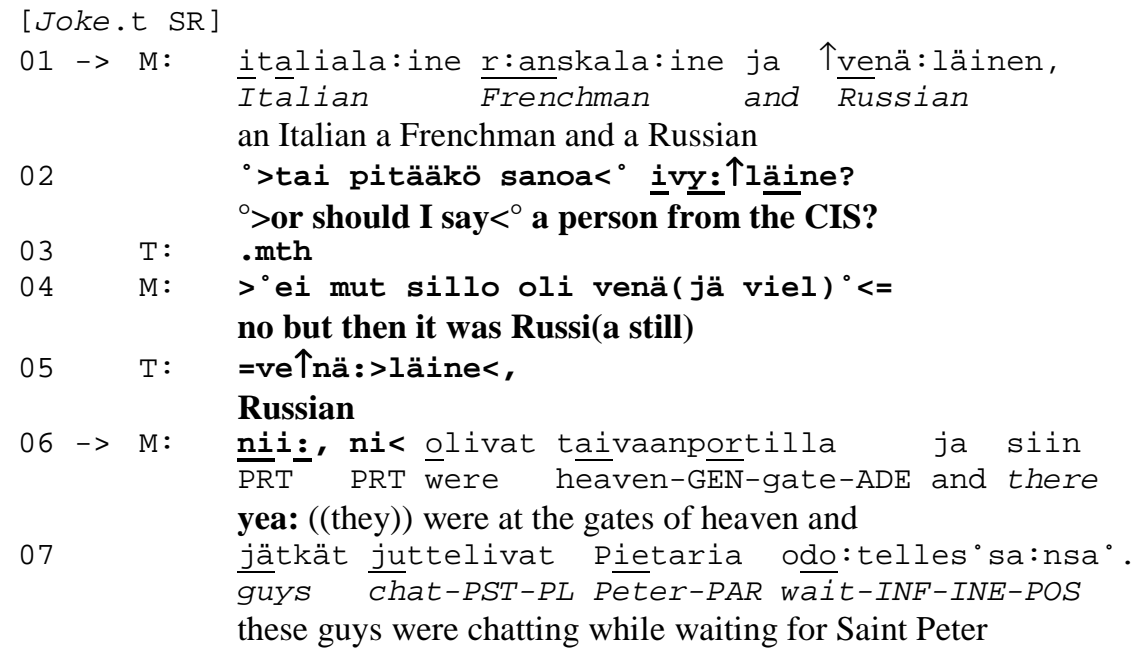

Example 8 shows a parenthesis which is located in between a reportative expression (line 2: Jaana£s-sano 'Jaana said') and the reported speech that it projects (line 4: et se aukee 'that it opens...'):

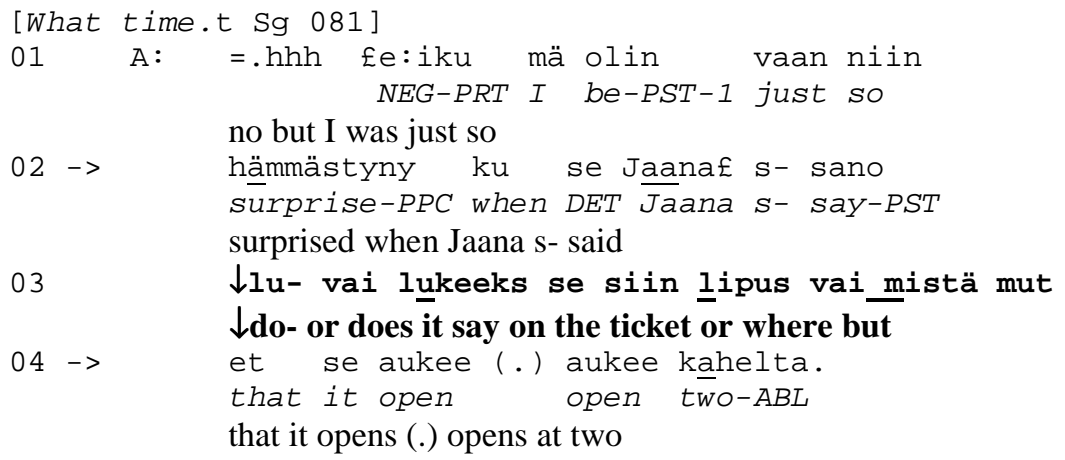

In example 9, the parenthesis follows the expression on - - korkea aika 'it's high time' (line 1) and precedes the infinitive verb phrase (line 3: se meidän viiri aikaansaada 'to get our streamer done'): 
(9)

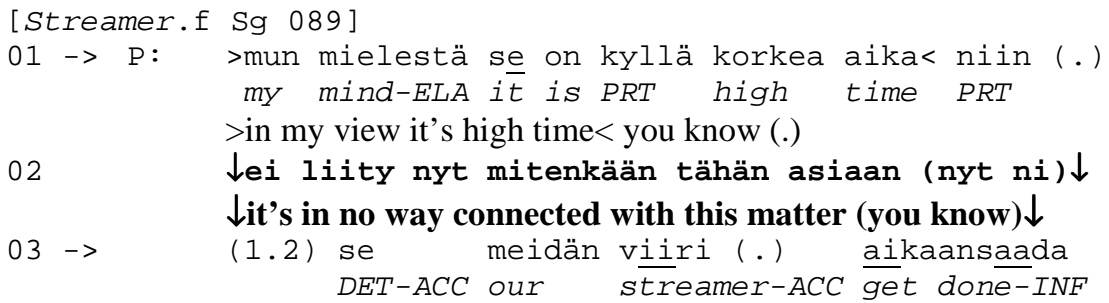

(1.2) to get our streamer (.) done

It should be noted that in Finnish the expression on korkea aika (tehdä jotakin) 'it's high time (to do something)' behaves syntactically like modal verbs expressing necessity (cf. Vilkuna 1996: 282, Laitinen 1997), such as täytyy pitää (tehdä jotakin) 'must (do something)': the lexical verb is in the infinitive form. Thus, the incompleteness of the frame construction is here due to the lack of the lexical verb (aikaansaada 'to get done'). ${ }^{3}$

Parentheses can also wedge their way into an NP, as in example 10 (lines 1, 4-6: semmoset - - söötit kasvot 'a kind of - - pretty face'):

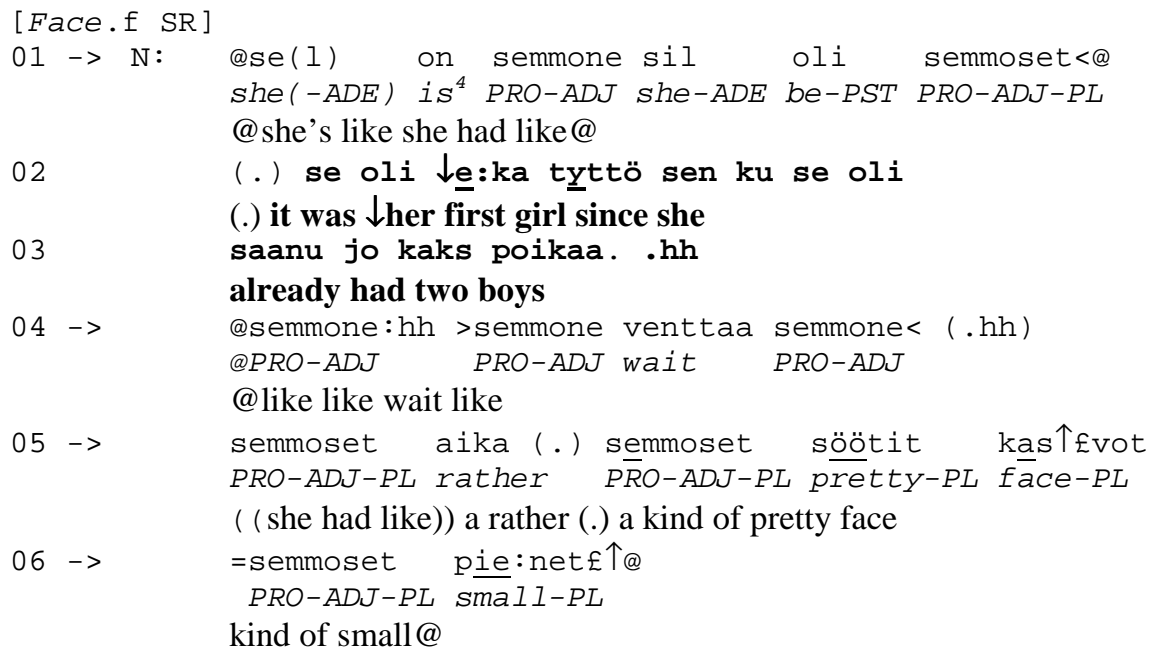

\footnotetext{
${ }^{3}$ At least two different kinds of analyses can be presented about the pronoun se 'it' at the beginning of the construction. On one hand, this pronoun can be viewed as a semantically dummy element that fills the preverbal slot in the linear structure of the utterance. On the other hand, the pronoun se can be perceived as having the same referent as the object NP se meidän viiri of the verb aikaansaada. In that case one possible translation of the utterance se(-ACC) on korkea aika se(-ACC) meidän viiri(-ACC) aikaansaada would be 'it should be finished without delay, this streamer of ours'. When processing a real time conversation, neither of these two alternative interpretations necessarily emerges more clearly than the other.

${ }^{4}$ In Finnish, the verb olla can have both the meaning 'to be' and 'to have'. In the latter case, the owner is indicated with an adessive NP, e.g. minu-lla on 'on me is'.
} 
In the Finnish version, the element semmoset (line 1) is a pro-adjective, which can function as an independent pronoun ('like that'), but especially in spoken Finnish it is also used as a kind of indefinite article in NPs categorizing or describing the referent (Erringer 1996, Tiainen-Duvallon 2002: 121-122, Juvonen forthcoming).

In our example, the pro-adjective semmoset projects a nominal head since the preceding context offers no basis for interpreting it. The incompleteness of this phrase is supported by prosody. The pro-adjective is not accompanied by utterance final prosodic characteristics such as a final fall, decelerando or creak. Instead, it ends with a turn-holding closure (here a dental stop) (cf. Ogden 2001), which has been marked in our transcription by a left-pointing arrow head $<$. It is also worth noting that progress of the construction is halted already after the first occurrence of semmone (line 1), where the speaker retreats back along the syntagmatic axis in order to repair the beginning of the construction:

\begin{tabular}{|c|c|c|c|}
\hline 11) & ace.f SR] & & \\
\hline $\begin{array}{l}\text { se }(1) \\
\text { she }(-A D E) \\
\text { sil } \\
\text { she-ADE }\end{array}$ & $\begin{array}{l}\text { on } \\
\text { is } \\
\text { oli } \\
\text { be-PST }\end{array}$ & $\begin{array}{l}\text { semmone } \\
P R O-A D J \\
\text { semmoset< } \\
P R O-A D J-P L\end{array}$ & (PARENTHESIS) \\
\hline
\end{tabular}

The inserted material is thus placed immediately after the repair which is understood as paradigmatic, and we may assume that an expectation about continuation has, at least partially, been formed already during the first $s e(l)$ on semmone 'she is/has like' fragment.

On the basis of empirical examples, it is difficult to propose any real syntactic limitations on the kinds of places where parentheses can appear (cf. also Blanche-Benveniste et al. 1990: 148-149). Nevertheless, it appears that they tend to be placed in slots where the syntactic and semantic incompleteness of the utterance is readily evident.

In our examples, prosodic features also support the impression of the syntactic and semantic incompleteness of the TCU. Beginnings of parentheses are often preceded by disruptions, such as pauses or stops. The boundary may also be marked by changes of pitch, rhythm or articulation. A parenthetical insert breaking the projection of the frame construction might, for instance, be uttered in a lower register than its surroundings (cf. downward-pointing arrows in transcriptions of examples 8 and 9) or more quietly and in a faster tempo than the surrounding (cf. markings ${ }^{\circ}>\ldots<^{\circ}$ in example 7) (cf. Local 1992). In example 10, instead, the speaker alters her voice quality in the main line of the narrative: she slurs her words through 
puckered lips while telling about the cute little baby. Parenthetical background information, by contrast, she presents in her normal voice. This reversal of markedness serves to remind us that prosodic cues cannot be interpreted without considering their context; they are interpretable only against their immediate environment (cf. Klewitz and Couper-Kuhlen 1999: 469-473).

\subsection{Sequential-textual projection}

In the previous examples, parentheses utilize the syntactic incompleteness of the sentence constructions. Parentheses can also be located between two syntactically complete constructions (cf. Sorjonen 2001a: 240-241). In example 12 , the linkage between the framing material is based on a sequential pattern being reported in the main line of talk:

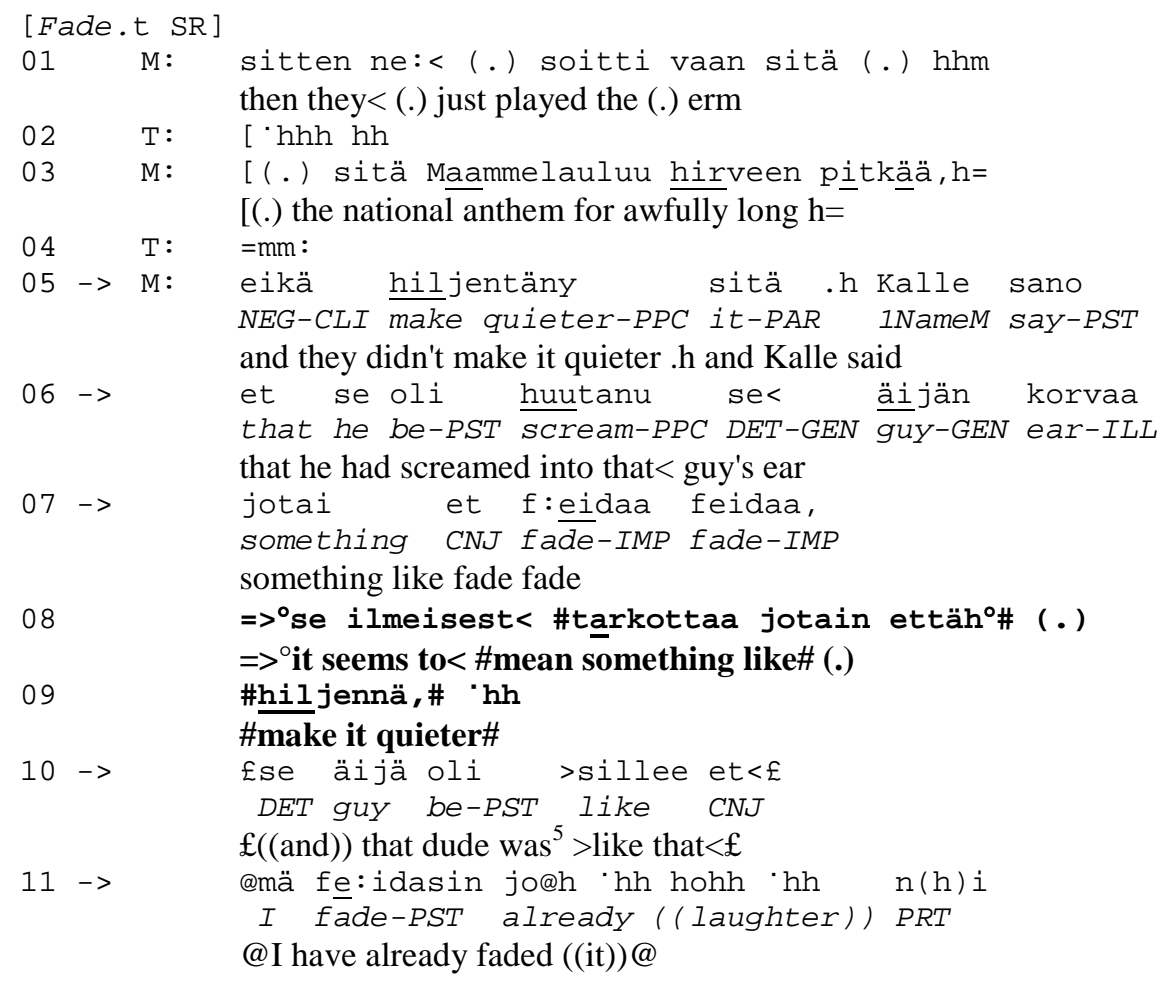

Here the narrative and turn are interpretable as incomplete on the basis of

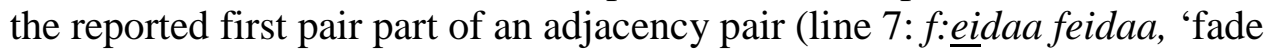
fade') after which the narrative progression is broken (lines 8-9). In an

\footnotetext{
${ }^{5}$ In young people's speech, the verb oli 'was' is frequently used in a quotative function (cf. e.g. Routarinne 1990: 27, Kajanne 1996: 228) just like in English (cf. be like + quote; Romaine and Lange 1991).
} 
ordinary organization of turn-taking, the speaker with the first pair part allocates the turn to the other participant. In a narrative context, the sequential implications of the first pair part function differently, however. Embedded in the narrative, the projection established with the first pair part seems not to entail a speaker change, but the continuation of the same speaker's turn, just as an incomplete syntactic construction would. In addition, the level intonation of the utterance indicates turn-holding. Thus, the frame of the parenthesis appears to be the adjacency pair consisting of a directive (line 7) and its response presented as reported speech (line 11).

\subsection{Return to the frame}

It is only possible to interpret the parenthesis at the stage where the speaker returns to the frame. In most cases, returning to the frame goes smoothly. First of all, the participant in the recipient position allows the speaker to continue after the parenthesis (see also the analysis of example 16 below, in section 4.2). This shows that the recipient treats the current speaker's turn as incomplete. There are also no signs at the interface showing that the participants had any real trouble returning to the frame construction again. Returning can sometimes be done directly, without any explicit markers such as connectors (see above example 12 line 10).

However, there is often some particle at the interface, and in Finnish this particle is very often $n i$ 'so, then' (see, for instance example 7 line 6 and below example 16). This particle indicates continuation of an argumentative or narrative line which had started earlier but which might have been interrupted (Vilkuna 1997: 63, Sorjonen 2001a: 270-273). Another hinge by which the return to the frame construction is performed can be the particle mut 'but', if the parenthesis is in a contrasting relationship to the frame construction (see example 8 line 3 and below example 18).

In addition to using a particle for marking the transition, the frame construction may be partially repeated or recycled. When resuming the main line of talk, the speaker thus jumps a step or two backwards along the syntagmatic axis. We may assume that the recipient recognizes the repeated material. The repetition thus functions as an explicit marker of a resumption. On the other hand, repetition also gives the speaker additional time to process the suspended construction, as can clearly be seen in example 10, which is now presented again for syntagmatic and paradigmatic analysis: 


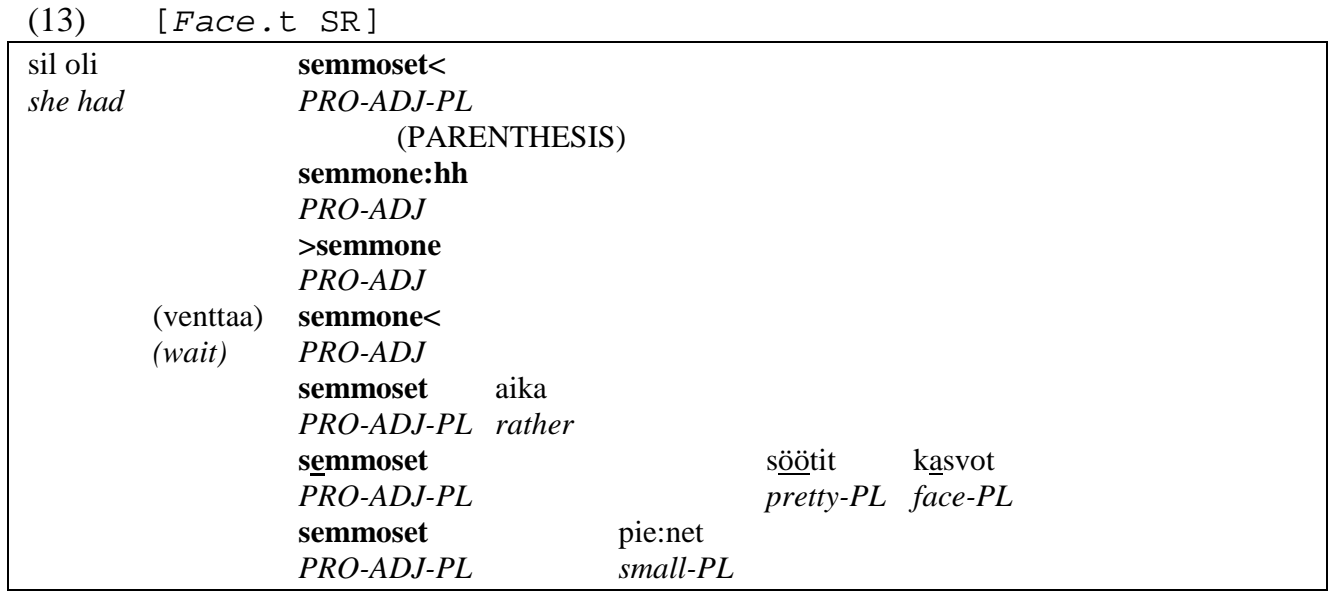

Above we noted that there are usually clear prosodic changes at the beginnings of parentheses. Returning to the frame can, by contrast, be more flexible. In example 12, only the beginning of the parenthesis contrasts prosodically with the frame construction (cf. also example 17 below). If, instead, the entire parenthesis is prosodically highlighted against the frame, the return to the frame can also be prosodically clearly marked for instance by a change in voice quality as is the case in example 10 above (subsection 3.1).

\subsection{Summary of the discussion of the frame construction}

A common feature of all our examples is that the projection of the turn is based either on the sequential or syntactic structure, and is often supported by prosodic cues (cf. Stoltenburg 2002). Indeed, parentheses utilize the anticipated trajectory of the construction or activity sequence.

Paradoxically, these "parasites" of their frame construction particularly tend to separate elements which are tightly linked by syntax or sequential structure. For example, the reported first pair part of an adjacency pair embedded within the narrative offers a recognizable slot for the second pair part before which a parenthetical insertion can be located. Within verb constructions, parentheses can not only wedge themselves between a verb and its arguments and other adjuncts, but also into the NP between the lexical head and its modifiers. Parentheses seem to find their way into sequences and TCUs at points of maximum incompleteness (c.f. Schegloff 1996: 93-94, Sorjonen 2001a: 217) where the current speaker's right to continue is beyond doubt.

\section{The relationship of insertions to the main line}

The syntactic autonomy of parentheses is manifested by their indifference to the structural ties of the frame. In addition, it is also impossible to predict 
the internal structure of an embedded insertion on the basis of the frame. Structurally, a parenthetical insertion can be just about anything: an utterance formed by one or more words, a chain of utterances or an adjacency pair, even a longer interactive sequence. Despite the lack of syntactic limitations and, especially, if we look at parentheses as parts of the sequential construction of a conversation, parentheses seldom seem wholly random or aimless (see also Mondada and Zay 1999). In this section, we focus especially on how speakers utilize parentheses in shaping wider sequences.

\subsection{Parenthesis as a metatextual comment}

Metatextual comments constitute one clearly distinguishable type of parenthesis (cf. Authier-Revuz 1993). They may comment on the current activity or some particular part of the frame construction, either its form or its contents. In example 14, the parenthesis organizes the semantic relatedness of the frame to the previously discussed topic:

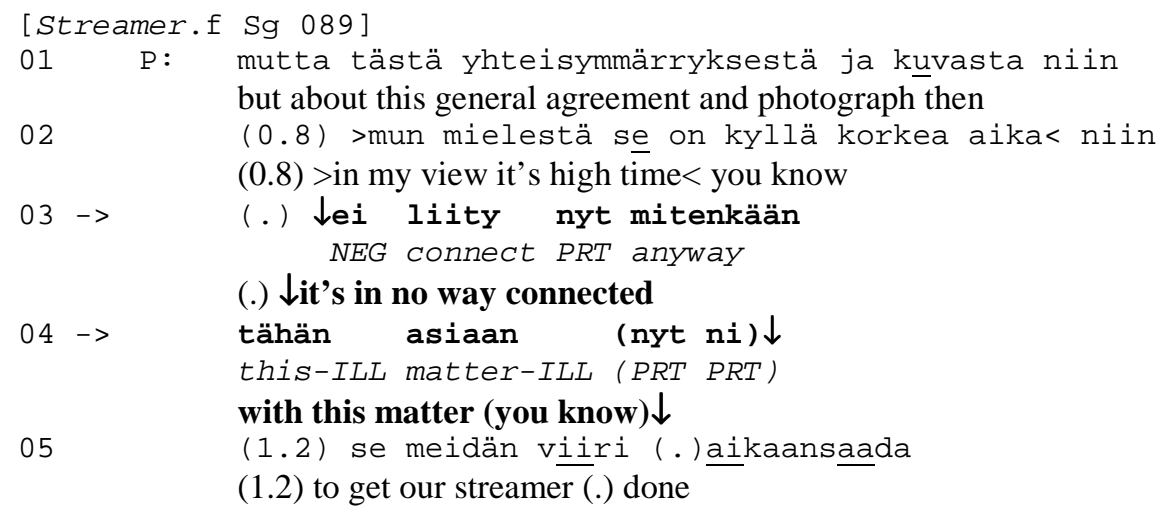

With the parenthesis, the speaker shows that he understands he is presenting the new subject in a slot where it is sequentially misplaced. Thus he takes the preceding discussion as a reference point to which later statements are related. Parentheses can be used as means to deviate from the trajectory predicted by the context.

In example 15, the parenthetical sequence is triggered by a slang word borrowed from English (fade > feidaa):

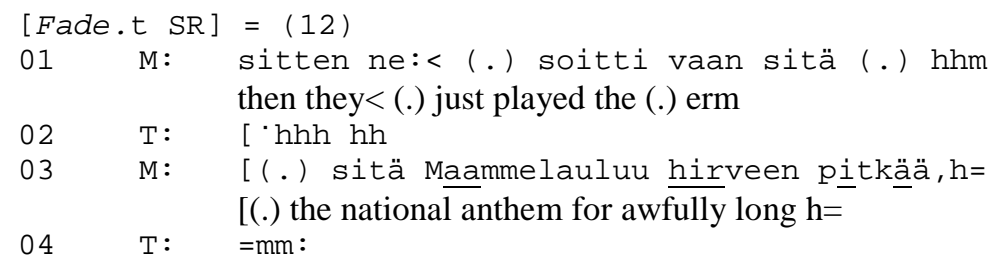




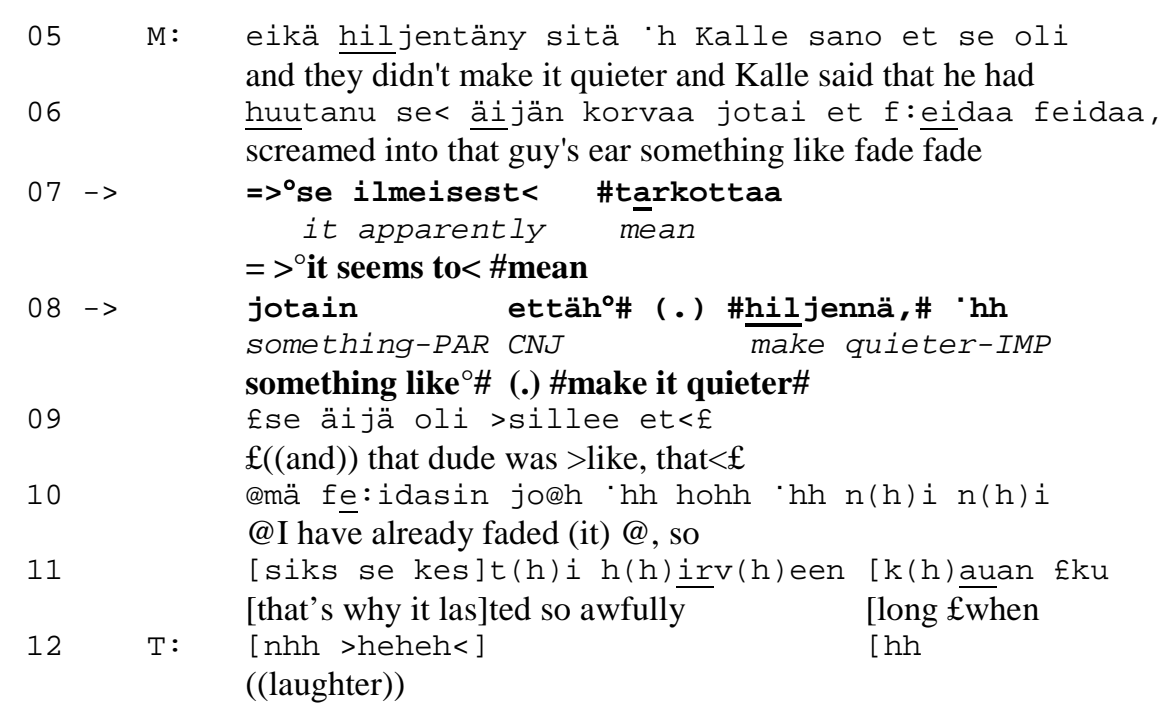

In the parenthesis, the narrator offers an explanation of the meaning of the word feidaa. She presents this information as her own inference (se ilmeisest tarkottaa 'it seems to mean'). Thus she can offer the explanation to the recipient without implying that the recipient does not know the meaning of the word.

Goodwin $(1984,1987)$ has pointed out how tellers can methodically use parenthetical inserts or forgetfulness presented in the middle of a structural unit. Not only can these means be used to introduce some information or facts missing in the conversation, but they can be used to delay the progression of the narrative, most typically just before its climax. This is a rhetorical device by which the recipients' attention is captured by the current speaker. In our example, we can note that the reported second pair part, delayed by the parenthesis but projected by the reported first pair part, evokes laughter in the recipient (line 12).

If we further look at the context preceding the parenthesis, we notice that direct reported speech is introduced by the expression jotai (et) 'something like'. The same material is repeated in the parenthesis before the standard language equivalent of the problem word (\#tarkottaa jotain ettäh \# (.) \#hiljennä 'it seems to mean something like (.) make it quieter'). When we examine how parenthetical inserts relate to the main line of talk, it is often possible to pick some element from the frame construction which gives impetus for getting side-tracked. In example 15, the trigger for the parenthesis is the word feidaa 'fade'. The expression jotai (et) 'something 
like' already prepares ground for the problem material and projects the metatextual parenthesis which will attract the recipient's attention. ${ }^{6}$

\subsection{Parentheses as a means to change the participation framework in a narrative sequence}

While parentheses interrupt the progression of the frame construction and leave it dangling in the air, as it were, they can also significantly shape the interaction, project how it will continue and create a 'horizon of expectations'.

In the context of conversation, story-telling is typically preceded by a pre sequence which consists of a story preface and its acceptance or rejection. In an unmarked pre sequence, the story preface of the intending teller immediately evokes from the recipient(s) a 'go ahead' to tell the story. (Cf. Sacks 1974, Schegloff 1990: 61, Routarinne 1997: 141, Sorjonen 2002: 166-167.) In the following extract, there is interactive trouble during the pre sequence. When looking at how the participants settle into the roles of the teller and recipient of the joke, we can identify several ways in which the recipient resists taking her role. There are two prefaces to Mira's story (lines 1, 4: (no) minäpä kerro(:n) v(:)itsin '(okay) I'll tell a joke'), but these are followed by pauses (lines 2,5) which delay the recipient's (Tiina's) reaction. The delay together with Tiina's turn design $m^{\prime} t a ̈$ ? 'what?' (line 3) and $h m h h$ (line 6) demonstrate that she does not display an immediate and obvious willingness to hear the joke.

Despite the recipient's reluctance, which jeopardizes the entire joke, Mira begins to tell it after the preface. The telling begins with a list of three terms in the nominative case expressing nationality (line 7: italialaine ranskalaine ja venäläinen 'an Italian a Frenchman and a Russian'). This list creates the expectation for a verb that would go with it. In addition, the list also reveals the joke's genre and projects the main line of the narrative. We know to expect a three-part joke: the endeavours of the Italian and the Frenchman create an expectation, and the Russian is supposed to comically break that expectation (cf. Sacks 1978: 252-256). Both syntactic and sequential-textual features thus define the turn's expected trajectory and show that both the wider narrative sequence and the immediate TCU are incomplete. However, at this very point the progression of the construction is broken. This obvious incompleteness after the beginning of the turn holds the turn for the speaker, since the turn is maximally in the speaker's grammatical control (cf. Schegloff 1996: 93-94). With respect to turn allocation, the speaker can afford a detour without losing her turn:

\footnotetext{
${ }^{6}$ Here the cues projecting a parenthesis and self-repair or word search seem to overlap (cf. e.g. Schegloff 1979, Sorjonen 1997: 118-119).
} 


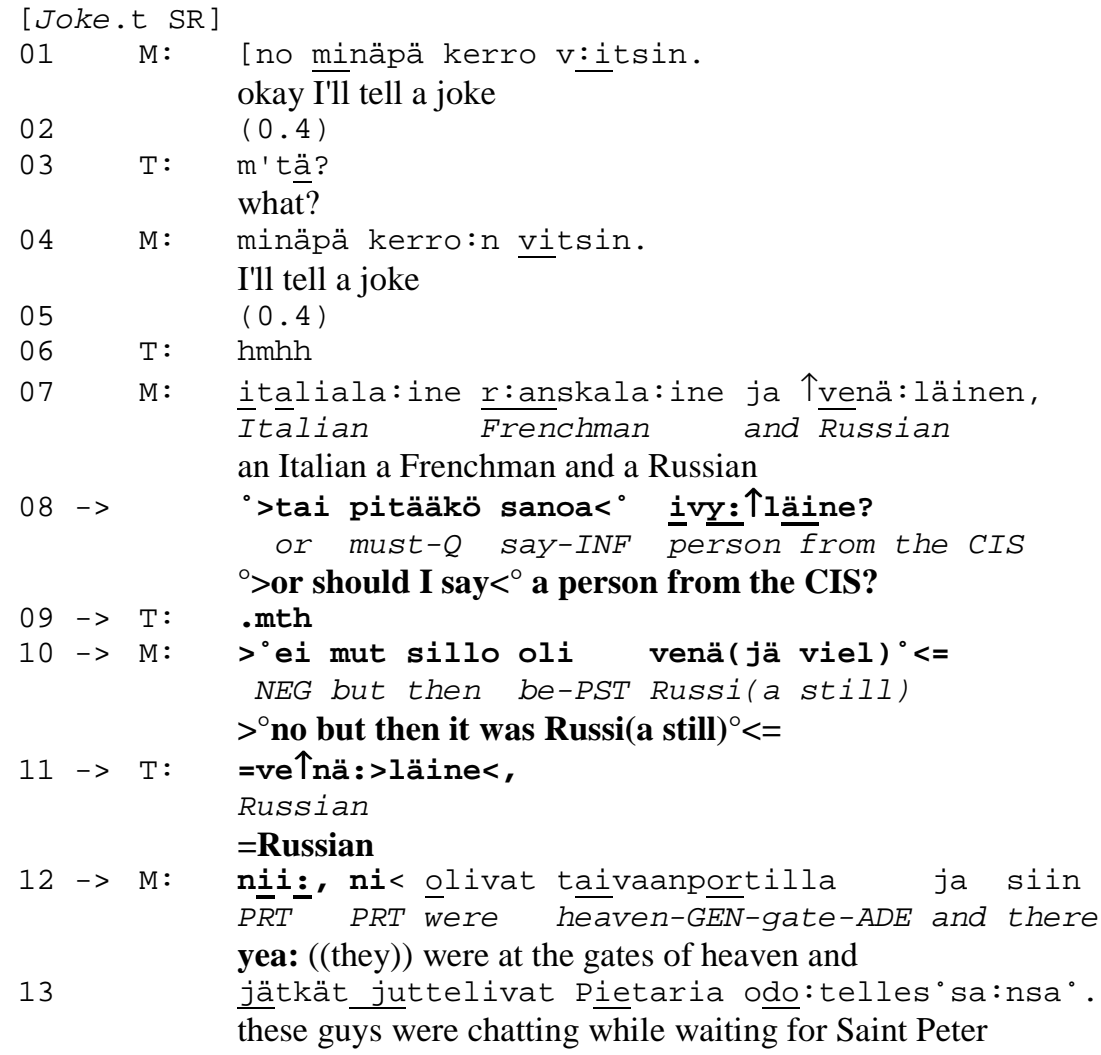

In line 8 , the parenthetical sequence is initiated by the interrogative utterance $\left({ }^{\circ}>\right.$ tai pitääk ö sanoa $<{ }^{\circ} \underline{\underline{i} v y:}$ : läine? 'or should I say a person from the CIS?'). It could be viewed as a word search addressed to the speaker herself. However, it does not manifest any turn-holding markers such as sound stretches, pauses and stops within the TCU or hesitations which are typically linked with genuine word searches (cf. Schegloff, Jefferson and Sacks 1977, Sorjonen 1997). Indeed, this somewhat ironic utterance has been formulated and produced in a way which invites a response from the other participant. By proposing another alternative to the last nationalityexpressing term, the teller reformulates the joke's stereotypic framework with an updating element (ivy: Tläine? 'a person from CIS?, line 8) which the unknowing recipient also has access to.

In the parenthetical interactive sequence (lines 8-12) the recipient's indistinct response (line 9: .mth) instead of a clear go ahead marker shows that there is still friction in the participation framework. In line 10, the statement of the intending teller (ei mut sillo oli venä(jä viel) 'no but then it was Russi(a still)') re-contextualizes the preceding question. It can also be heard as her own suggestion to end the parenthetical sequence. In any case, 
this additional information that Mira offers finally evokes a verbalized response from the recipient. Tiina's response ve T̂ä:>läine 'Russian' (line 11) displays her interpretation to be that the first pair part is still valid. By participating in the choice of word, Tiina displays a more active recipiciency than previously. The teller accepts the term with the particle nii (line 12) and returns to the telling the joke by using the particle $n i$ (cf. Sorjonen 2001a: 271).

Our example illustrates the potential of metatextual parentheses. On the one hand, it shows a negotiation over a choice of words. As an activity, the parenthetical sequence also proves to be a means for influencing the participation framework. This detour is a way of reacting to problems in the participant roles and displays how the teller monitors the recipient's responses. The parenthetical sequence invites the recipient to more actively join in the current activity. Within a syntactically unified frame construction it is thus possible to embed a complete parenthetical interactive sequence consisting of several TCUs and more than one turn and one speaker.

4.3 Parentheses as providing forward-oriented interpretative cues Metatextual embeddings focusing on a particular word are typically located as close to the problem material as possible, either immediately following or preceding it (Authier-Revuz 1993, Zay 1995). ${ }^{7}$ In the above examples, parentheses contain typical metatextual statements (ei liity tähän 'it's not connected with this', tarkoittaa jotakin 'mean something', tai pitääkö sanoa 'or should I say'). The next example also concerns a metatextual statement. However, the perspective differs from the examples we have discussed above:

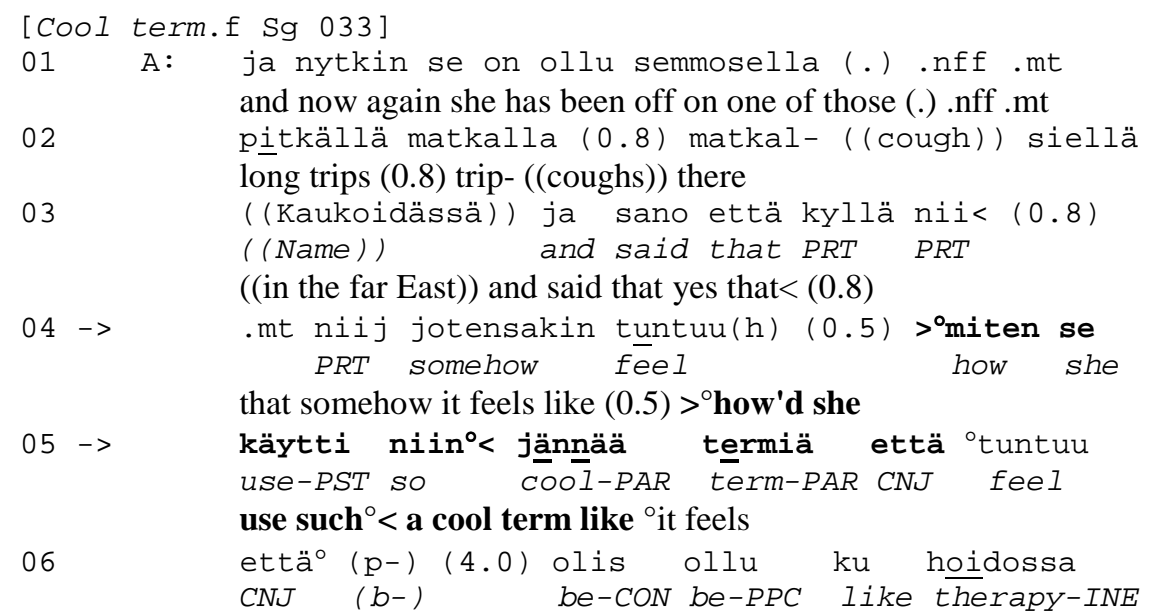

${ }^{7}$ In this respect as well, parentheses have the same properties as self-repairs. Both are typically done as close to the problem-causing material as possible. 


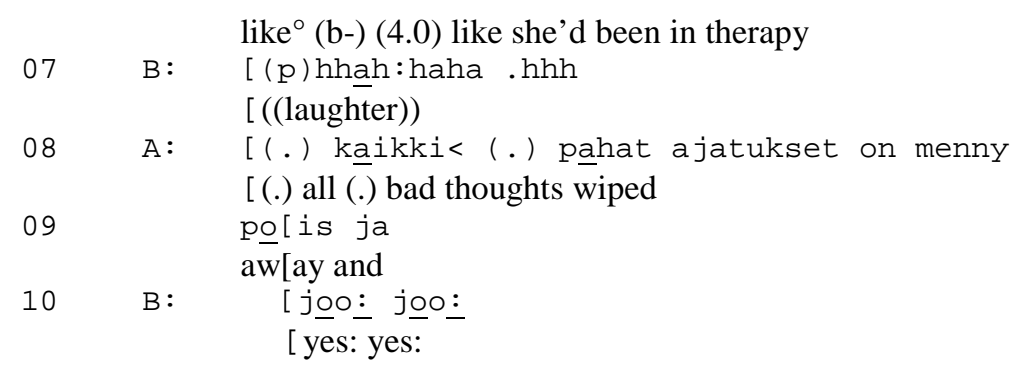

In the parenthesis $\left(>^{\circ}\right.$ miten se käytti niin ${ }^{\circ}<$ jännää termiä että 'how'd she use such a cool term like') which begins at line 4 and interrupts the quote, the referential anchoring is the same as in the reportative clause (line 3: ja sano 'and said'). The interrogative form of the expression, however, makes it evident that, at the moment, there is an ongoing word search. Here the parenthesis delays, but also clearly projects, the material in the frame it is oriented towards. The verb tuntuu 'feel' which precedes the interruption and is also repeated after the parenthesis, as well as the way the parenthetical sequence is formulated, project a continuation and evoke expectations about its syntactic form and semantic content (tuntuu joltakin 'feels somethingABL' or tuntuu että kuin 'feels like').

Prosodically, the parenthesis is divided into two parts. ${ }^{8}$ Thus, prosodic contextualization does not always remain the same throughout the parenthesis, but speakers can also slide back to their normal registers (see also section 3.3) or highlight something within the parenthesis, as is the case here. The beginning is produced more quietly and faster in contrast to its surroundings, which also emphasizes the fact that the frame construction has been broken. The end of the parenthesis, jännää termiä 'cool term', is a characterization. It is presented more loudly, which suggests that it will be significant in what follows.

Goodwin (1996: 383-385, see also Sacks 1974) calls expressions of the same type as jännä termi 'cool term' for prospective indexicals. By the term he refers to classifications or descriptive terms that can function cataphorically in cases where the recipient has no access to the characterization. As prospective indexicals, they offer an interpretation framework which should be applied to the talk that follows. They also hint at the type of response which is expected. In the current example, the completion of the frame construction (lines 5-6: ' tuntuu että ${ }^{\circ}(p-)$ (4.0) olis ollu ku hoidossa 'it feels like (b-) (4.0) like she'd been in therapy') might not quite live up to the expectations the prospective characterization evokes,

\footnotetext{
${ }^{8}$ The frame construction is also prosodically noteworthy since it contains a turn-holding glottal closure (line 3) (see Ogden 2001) as well as a pause which breaks the rhythm and anticipates a digression (cf. Klewitz and Couper-Kuhlen (1999).
} 
i.e. the speaker does not quote any 'cool term' in her completion.

Nevertheless, the recipient assesses the completion with laughter (line 7).

\subsection{Parenthesis in negotiating the structures of conversation}

Forward-oriented parentheses, which provide additional background information and steer reception, create dramatic tension when the recipient has no access to the situation being spoken of (cf. example 17 above). This subsection discusses what may happen when the recipient also knows something about the matter at hand.

In example 18, the participants (Brita and Aira) talk about going to a rock concert with a third female friend, Jaana. Prior to the excerpt, Aira has said that she brought Jaana her concert ticket and only then noticed that the concert will be held during the week. In addition, Aira has said that it is odd that the concert supposedly begins at two. Brita has then explained to her that the crowd will be allowed to enter the concert venue starting at two, but that the band won't begin to play until around six. Another concert has been touched upon, too.

At the beginning of the example below Aira makes an inquiry which leads not to an answer but to an extended repair sequence (see the long pause at line 2, Brita's NTRI at line 3, her candidate understanding at line 5, and finally the turn at line 7 which is filling the second pair part slot without doing the action required by the first pair part, i.e. the answer does not provide the information asked for). Line 8 onwards, Aira's turn, which also contains the parenthetical insertion of interest here, is connected to the inquiry sequence she had begun before, functioning as an additional background account. Such an account is sequentially relevant since the recipient has treated the question in line 1 as problematic. The turn at line 8 returns to the previously discussed question about the starting time of the concert:

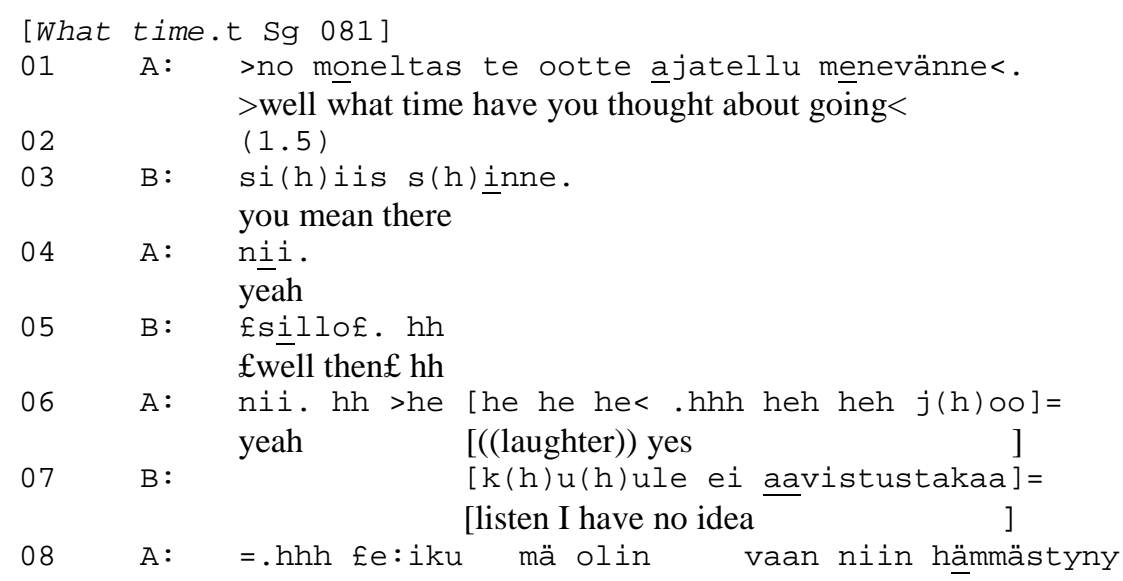


NEG-PRT I be-1-PST just so surprise-PPC

£no really I just was so surprised

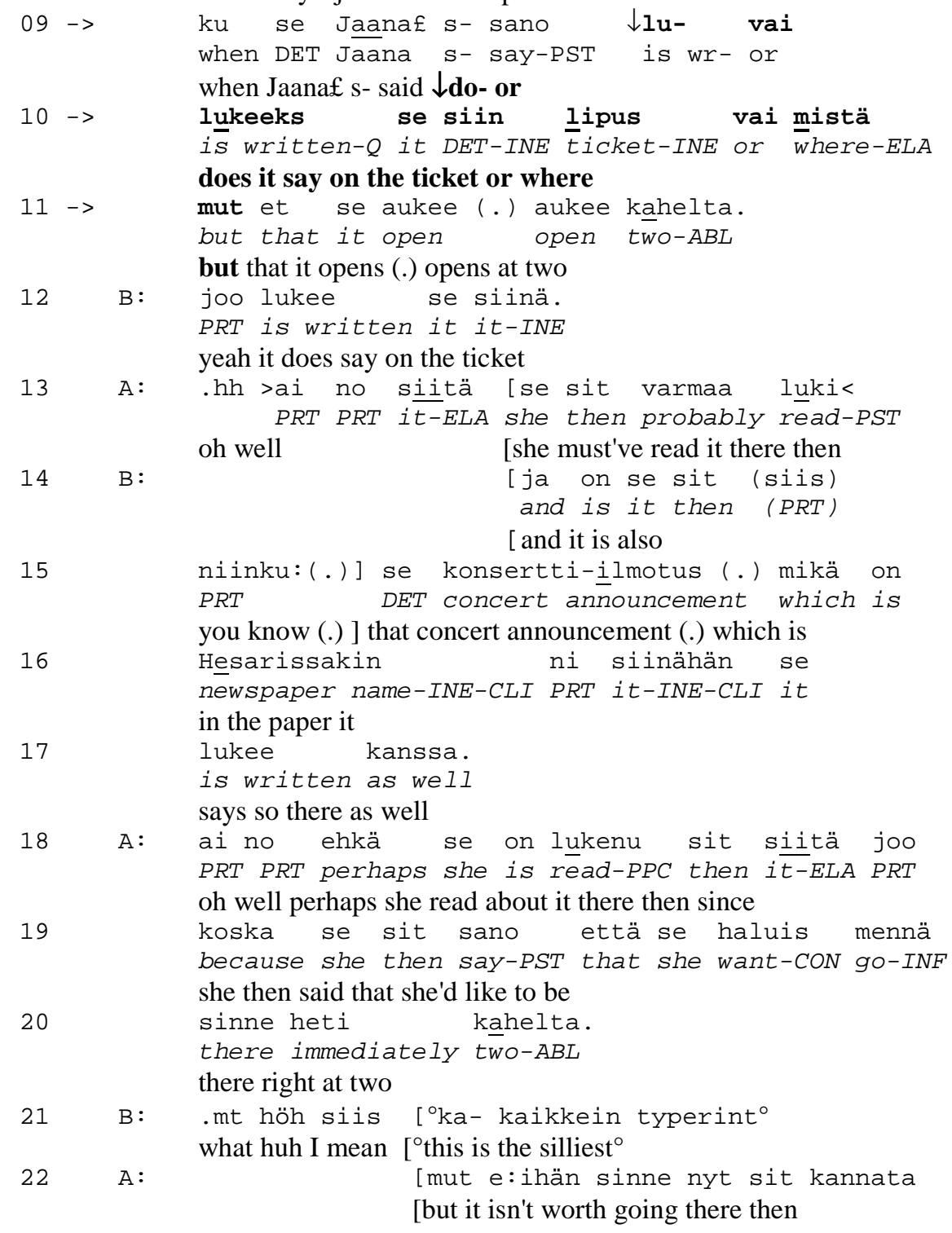

The embedded insertion beginning at line 9 (lu-vai lukeeks se siin lipus vai

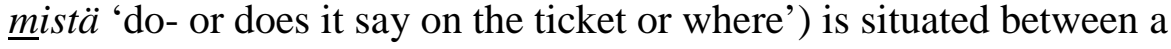
reportative clause and reported speech (cf. section 3.1). The frame construction of the parenthesis (lines 8-9, 11: =.hhh £e:iku mä olin vaan niin hämmästyny ku se Jaana£ s- sano - - mut et se aukee (.) aukee kahelta. 'no, really, I was just so surprised when Jaana s- said - - that it [the concert venue] opens (.) opens at two') is an utterance which recycles a previous claim modifying its content and in the form of reported speech. More 
precisely, the information which has been corrected by the other speaker (i.e. what happens at 2:00 pm is the opening of the concert venue, not the starting of the concert) is now presented here as something someone else (Jaana) said. Additionally, the expression of affect ('I just was so surprised') seems to motivate the parenthetical insertion. With the help of the parenthesis, the current speaker provides an interpretation that would lighten the socially problematic and delicate implications expressed by the affective formulation concerning the reported issues.

The parenthetical statement is an interrogative (cf. also examples 7, 16 and 17). The interrogative modality is contrasted with the frame construction's declarative form, and the return to the main line of talk hinges on the particle mut 'but' (line 11) (cf. Mazeland and Huiskes 2001). The parenthesis is shaped and situated in such a way that it is only possible to interpret it after the speaker has returned to the frame. More specifically, the basis for interpreting the pronoun se 'it' is not offered until the latter part of the frame (lukeeks se siin lipus 'is it [that it opens at two] written on the ticket', see lines 10-11). This shows how the use of referring expressions is a sign of cohesion which intertwines the main line of the discourse and the parenthesis (cf. Zay 1995, Duvallon forthcoming).

The embedded question (lines 9-10) may first seem to be rhetorical since Aira does not leave a slot for answering. However, after the referential interpretation of the insertion is made accessible to the recipient, Brita's turn at line 12 (joo lukee se siinä 'yeah it does say on the ticket') invites us to consider the interrogative as a genuine question. In other words, the recipient utilizes the interrogative form of the parenthesis by treating it as the first pair part of an adjacency pair. The link between the first and the second pair part, which are physically separated, is constructed through the repetition of the same syntactic schema and the same lexical material (see also Fox 1987: 26-36, Tiainen-Duvallon 2002: 220-226, 251-281, 294-318). Note that in Finnish the word order of not only polar questions but also confirming answers begins with a verb (on polar interrogatives in Finnish see Hakulinen 2001, Sorjonen 2001b):

(19) [What time.t Sg 081]

\begin{tabular}{|llll|}
\hline line 10: & lukeeks & se & siin lipus \\
& is written- $Q$ & it & on the ticket \\
line 12: & lukee & se & siinä \\
& is written & it & on it \\
\hline
\end{tabular}

By interpreting the interrogative embedded in the parenthesis as a genuine question, Brita alters the trajectory and participation framework of the conversation. She elevates the issue of what evidence Jaana has for saying what she said to the status of main line. By doing this, Brita, as a knowing 
participant, becomes the one to advance the main line: Aira receives Brita's answer (line 12) as news (she begins with ai 'oh', line 13) and Brita grabs the slot offered by the news receipt to further clarify the information (lines 14-17) (see Terasaki 1976: 4-9, Button and Casey 1984: 181-183, Sorjonen 1999: 175).

However, friction emerges in setting the trajectory of the conversation. The example evolves around the polyvalency of the Finnish verb lukea 'be written/read.' This verb can be used in constructions with various organizations and meanings, while their English counterparts need two different lexemes for their expression. In line 13, Aira constructs her turn of receiving the news on the verb lukea which was already present in the conversation, but changes the construction in such a way that the subject's semantic role appears as agentive (se lukee siitä-ELA 's/he reads [something] on it'). Another alternative is to use the verb in the sense of the English 'it is written' construction, as is done in the parenthetical expression (se lukee siinä-INE 'it is written on it'), in which case the subject is nonagentive and is interpreted as something. Indeed, the pronoun se in line 13 picks the story's protagonist Jaana as its referent. Thus it appears that Aira is already attempting to turn the trajectory of the conversation back to the narrative. However, at lines 14-17, Brita goes on to formulate her utterance as a continuation of the parenthesis both with respect to its structure, semantics and type of activity. Finally, in line 19, Aira manages to return to the narrative, with the help of a link she creates with the conjunction koska 'since/because' (ehkä se on lukenu siitä joo koska se sit sano... 'perhaps she read [about it] there then since she then said...').

In example 18, a subplot which was initially intended as a parenthetical offers itself as an opportunity for the other participant to influence the design and direction of the sequence. This example shows that the structures of a conversation are negotiable and that other participants in the conversation besides the current speaker have a possibility to influence its formation.

\section{Conclusion}

The starting point of our analysis has been to characterize parentheses as constructions which temporarily suspend the progression of some other syntactic construction or wider action sequence. In their most characteristic form, parentheses are independent constructions which neither syntagmatically complement their frame construction nor are in a paradigmatic relationship to it. A parenthetical segment is recognized only in relation to its environment. A prerequisite of such an interpretation is that the textual or sequential relationship between the frame construction and the framed segment is seen as hierarchical. 
The syntactic independence of the parenthesis and the frame construction is supported by at least three facts. Firstly, you cannot predict the internal structure of a parenthetical insert on the basis of the frame construction. Secondly, even though there may be solid linkages between the parts of the frame construction, based on syntax or sequentiality, they do not prevent parentheses from being inserted. It therefore looks like parentheses utilize specifically those syntactical or sequential places where an expectation for continuation is evoked. The use of parentheses plays it safe: when the progression of the turn and the construction is interrupted, its projection has already been created either on syntactic or sequential grounds. Thirdly, prosodic context cues support the perception of structural, semantic and actional separateness of the frame and the parenthesis. Here it is specifically the contrasting of different cues which makes the discontinuity and the juncture hearable. In addition, prosodic marking seems to be more apparent at the point where the frame is interrupted than when one returns to it.

Sequentially, several systematic characteristics can be found in the occurences of parentheses. It is usually possible to identify a triggering feature in the main line of the conversation, one which motivates the parenthetical sequence. The semantic link between the frame construction and the parenthesis can be constructed upon some specific linguistic element. This is typical especially of metatextual comments concerning a specific lexeme. Affective espressions also seem to motivate parentheses. More generally, parentheses are linked to critical phases in the semantic formulation or sequential action in the main line. These triggers may be more extensive than just a particular linguistic element.

An ongoing activity in the main line of talk can be readjusted by the parenthesis in various ways. Although the parenthetical sequence temporarily halts the progression of the main line, it often also projects and significantly shapes expectations of what is to follow. Parentheses are excellently-suited to the management of interactive activity, for example by shaping the participation framework to fit to the present activity. Another typical task of parentheses is to provide a background for a narrative. Background-providing parentheses not only orient the recipient(s) to the circumstances at the time when the event took place but can also steer the interpretation of the narrative's contents.

We have argued that parentheses utilize the expected trajectory of the current turn and structure. This idea is based on the first basic rule of the organization of turn taking, namely that each participant is entitled to one TCU at a time. Parentheses are one means offered to the speakers by the grammar of interaction that allows them to expand their turn without having to negotiate this with the other participants. When the progression of the 
main line of talk is suspended, the initial system of turn-taking freezes, as it were. A parenthetical insertion can then develop into an exchange allowing a subordinated turn for other participants but without cancelling the previous speaker's right to resume the halted turn.

Information presented in parenthetical sequences may also change the trajectory of the main line. This shows that all structures of a conversation are adjustable to the situation. They are not predetermined, but undergo constant negotiation. This negotiation can take place between the participants, but an alternative to it is monitoring of one's own talk. It is worth noting that participants nevertheless attempt systematically to resume a previous activity which has been deviated from.

One of the essential questions is what kind of structural knowledge conversation as an activity is based upon. In this article we have tried to expound two views linked to interactional linguistics. By analyzing parenthetical inserts, we have illustrated that linguistic structures are real tools for speakers, tools that they use to recognize and form hypotheses about the structural units under construction. We have also illustrated factors which show that the participants' grammar includes information both on syntactic structures and on construction of activities. Syntactic structures and sequential activities are equally parts of the toolbox of the grammar of interaction, used for predicting and regulating the progression of turns.

In section 2.1, we noted that the phenomenon we call parenthesis shares some characteristics with what is called self-repairs. Both interrupt the syntagmatic progression of the utterance and use the same markers to indicate the point of interruption. However, discontinuity between the frame and the parenthesis gives reason for further clarifying the relationship between these phenomena. If replacements and modifying repairs can typically be described as the speaker's movement back and forth along the syntagmatic and paradigmatic axes of the ongoing construction, then parenthesis on the other hand would seem to remain outside of this twodimensional representation.

In the textual fabric, parentheses form a third dimension to which the speaker can digress. By opening a parenthetical sequence, speakers place themselves outside the activity they are currently advancing, becoming an outside observer, as it were. From this vantage point they can, either alone or together with the recipient, not only regulate the semantic progression of the turn but also more widely shape the conditions of the action and interpretation. 


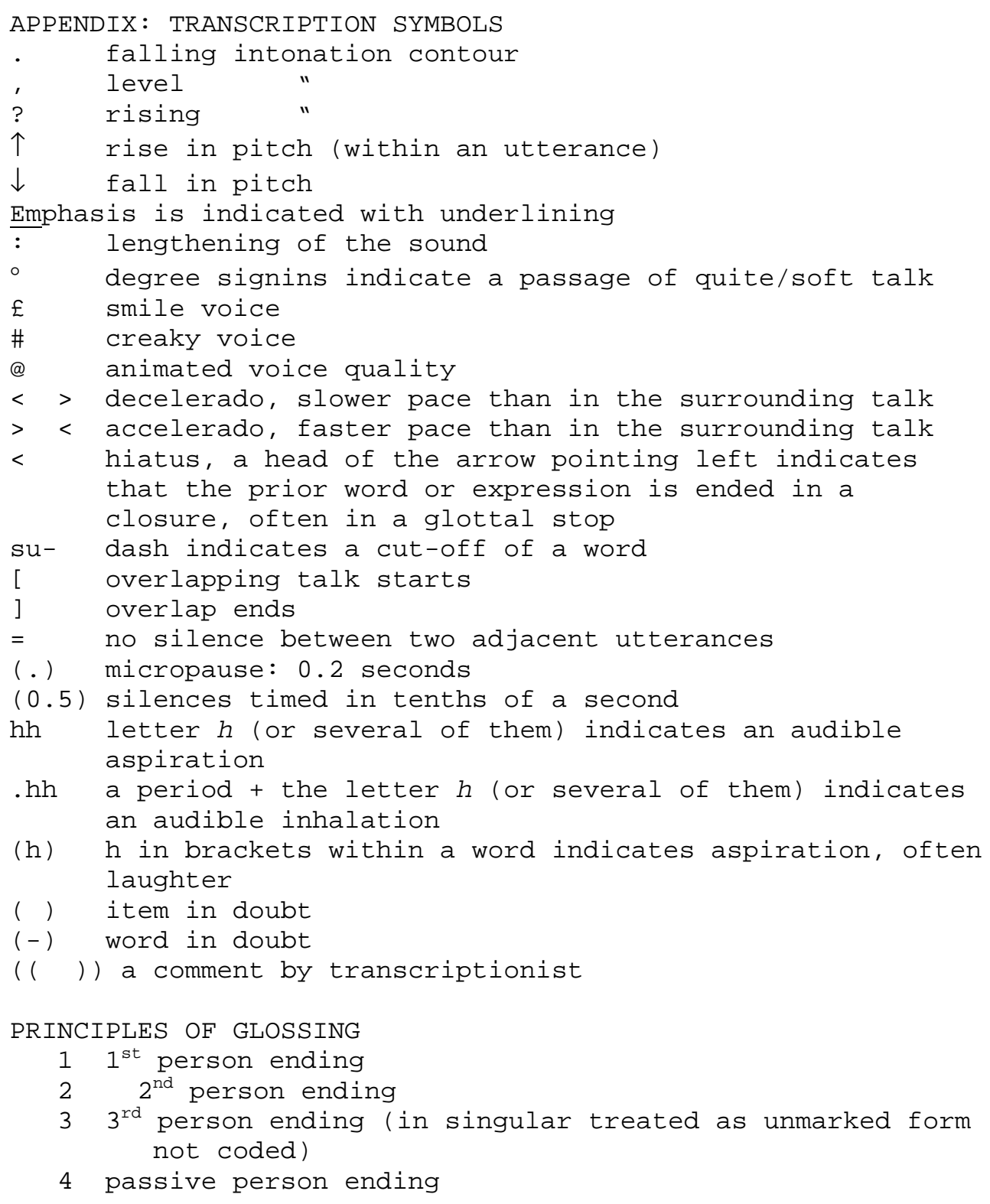

\section{Case endings}

Ablative

Accusative

Adessive

Genitive

Elative

Illative

Inessive

Nominative

Partitive

abbreviation
ABL
ACC
ADE
GEN
ELA
ILL
INE
NOM
PAR

\author{
approximate meaning \\ from \\ grammatical object \\ at, on \\ possession \\ out of \\ into \\ in \\ unmarked form, not coded \\ partitiveness
}




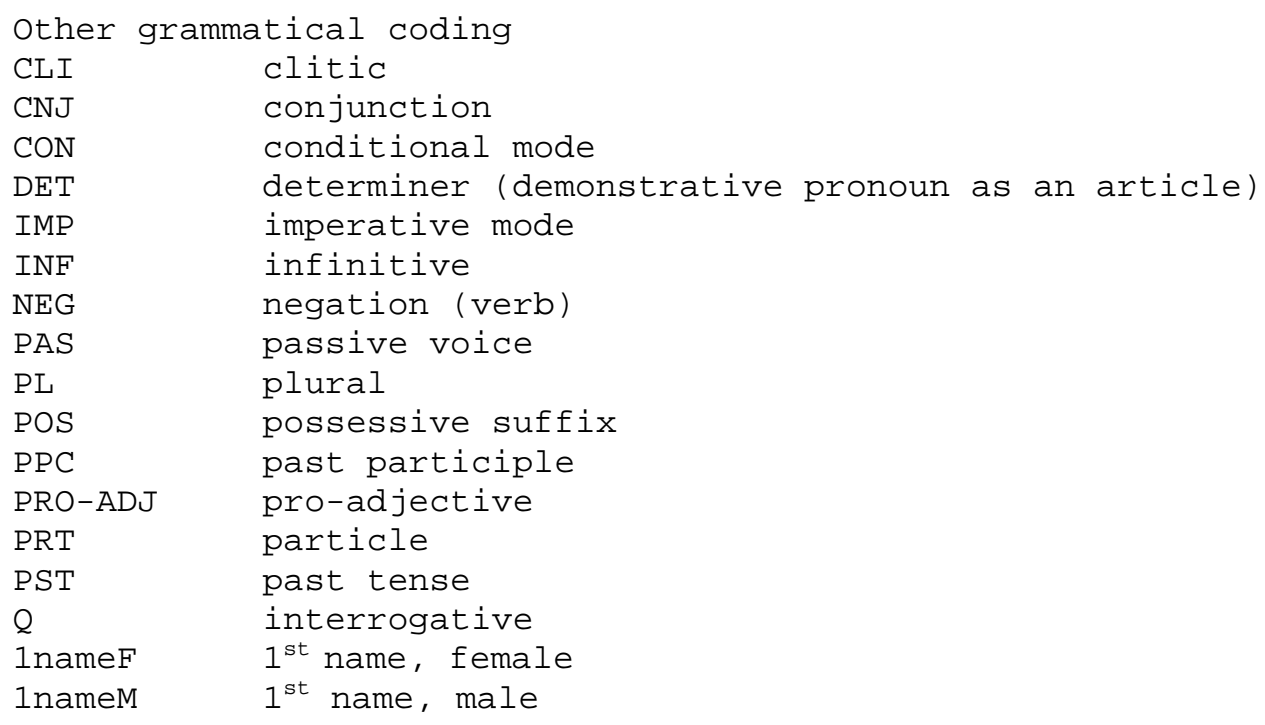

\section{References}

Auer, Peter, this volume. "Delayed self-repairs as a structuring device for complex turns in conversation.

Authier-Revuz, Jacqueline 1993. "Jeux méta-énonciatifs avec le temps.” In: Temps et discours, Herman Parret (ed.), 87-105. Louvain: Presses universitaires de Louvain.

Berrendonner, Alain 1993. "Périodes." In: Temps et discours, Herman Parret (ed.), 47-61. Louvain: Presses universitaires de Louvain.

Blanche-Benveniste, Claire 1990. "Un modèle d'analyse syntaxique "en grilles" pour les productions orales.” Anuario de Psicologia 47: 11-28.

Blanche-Benveniste, Claire 1997. Approches de la langue parlée en français. Paris: Ophrys.

Blanche-Benveniste, Claire; Bilger, Mireille; Rouget Christine and van den Eynde, Karel 1990. Le français parlé. Études grammaticales. Paris: Éditions du CNRS.

Blanche-Benveniste, Claire; Deulofeu, José; Stefanini, Jean and van den Eynde, Karel 1987. Pronom et Syntaxe. L'approche pronominale et son application au français. Paris: SELAF.

Button, Graham and Casey, Neil 1984. "Generating topic: the use of topi initial elicitors." In: Structures of social action. Studies in conversation analysis, J. Maxwell Atkinson and John Heritage (eds.), 167-190. Cambridge: Cambridge University Press.

Couper-Kuhlen, Elizabeth and Selting, Margret 2001. "Introducing interactional linguistics.” In: Studies in Interactional Linguistic, Margret Selting and Elizabeth Couper-Kuhlen (eds.), 1-22. Amsterdam: John Benjamins.

Duvallon, Outi forthcoming. "The pronoun se in the context of syntactic and discursive ruptures of spoken texts." In: Minimal reference: The use of pronouns in Finnish and Estonian, Ritva Laury (ed.). Helsinki: Finnish Literature Society.

Duvallon, Outi and Routarinne, Sara 2001. "Parenteesi keskustelun kieliopin voimavarana." In: Keskustelunanalyysin näkymiä. Kieli 13, Mia Halonen and Sara Routarinne (eds.), 122-154. Helsingin yliopiston suomen kielen laitos. 
Erringer, Anu 1996. The functions of demonstrative adjectives semmoinen, tämmöinen and tuommoinen in Finnish conversations. MA Thesis. Department of linguistics, University of Colorado, Boulder.

Ford, Cecilia E. and Thompson, Sandra A 1996. "Interactional units in conversation: syntactic, intonational, and pragmatic resources for the management of turns." In: Interaction and Grammar, Elinor Ochs E., Emanuel A. Schegloff and Sandra A. Thompson (eds.), 134-184. Cambridge: Cambridge University Press.

Fox, Barbara A. 1987. Discourse structure and anaphora. Cambridge: Cambridge University Press.

Goodwin, Charles 1979. "The interactive construction of a sentence in natural conversation." In: Everyday Language: Studies in Ethnomethodology, George Psathas (ed.), 97-121. New York: Irvington Publishers.

Goodwin, Charles 1984. "Notes on story structure and the organization of participation." Structures of Social Action, J. Maxwell Atkinson and John Heritage (eds.), 225246. Cambridge: Cambridge University Press.

Goodwin, Charles 1987. "Forgetfulness as an Interactive Resource.” Social Psychology Quarterly 50,2: 115-131.

Goodwin, Charles 1996. "Transparent vision.” In: Interaction and grammar, Elinor Ochs, Emanuel A. Schegloff and Sandra A. Thompson (eds.), 370-404. Cambridge: Cambridge University Press.

Goodwin, Marjorie Harness and Goodwin, Charles 1986. "Gesture and coparticipation in the activity of searching for a word." Semiotica 62: 51-75.

Hakulinen, Auli 1993. "The Grammar of Opening Routines." Yearbook of the Linguistic Association of Finland 15: 149-170.

Hakulinen, Auli 2001. "Minimal and non-minimal answers to yes-no question." Pragmatics 11: 1-15.

Hakulinen, Auli et al. forthcoming/ in print. Iso suomen kielioppi. Helsinki: Finnish Literature Society.

Helasvuo, Marja-Liisa 2001. Syntax in the making: the emergence of syntactic units in Finnish conversation. Amsterdam: John Benjamins.

Heritage, John 1984. Garfinkel and ethnomethology. Cambridge: Polity Press.

Holmberg, Anders and Nikanne, Urpo. 1993: "Introduction." In: Case and other functional categories in Finnish syntax, Anders Homberg and Urpo Nikanne (eds.), 1-20. Berlin: Mouton de Gruyter.

Jakobson, Roman 1956. "Two Aspects of Language and Two Types of Aphasic Disturbances.” In: Fundamentals of Language, Roman Jakobson and Morris Halle, 53-82. The Hague: Mouton.

Jefferson, Gail 1972. "Side sequences." In: Studies in social interaction, David Sudnow (ed.), 294-338. New York: Free Press.

Juvonen, Päivi forthcoming. "On the pragmatics of indefinite determiners in spoken Finnish.” In: Minimal reference: The use of pronouns in Finnish and Estonian, Ritva Laury (ed.). Helsinki: Finnish Literature Society.

Kajanne, Milla 1996. "Kertomus, referointi ja kerronnan valta." ['Story, quotation and the power of telling'] In: Suomalaisen keskustelun keinoja II. Kieli 10, Auli Hakulinen (ed.), 207-242. Helsingin yliopiston suomen kielen laitos.

Klewitz, Gabriele and Couper-Kuhlen, Elizabeth 1999. "Quote - unquote? The role of prosody in the contextualization of reported speech sequences." Pragmatics 9,4: 459-485.

Laitinen, Lea 1997. "Norms made easy: case marking with modal verbs in Finnish.” In: Taming the Vernacular, Jenny Cheshire and Dieter Stein (eds.), 110-124. London and New York: Longman. 
Lerner, Gene H. 1991. “On the syntax of sentences-in-progress.” Language in Society 20: 441-458.

Local, John 1992. "Continuing and restarting." In: The contextualization of Language, P. Auer and A. Di Luzio (eds.), 273-296. Amsterdam: John Benjamins.

Mazeland, Harrie and Huiskes, Mike 2001. "Dutch 'but' as a sequential conjunction: Its use as a resumption marker.” In: Studies in interactional linguistics, Margret Selting and Elizabeth Couper-Kuhlen (eds.), 141-169. Amsterdam: John Benjamins.

Mondada, Lorenza and Zay, Françoise 1999. "Parenthèses et processus de configuration thématique: vers une redéfinition de la notion de topic." Pragmatics in 1998. Selected Papers from the $6^{\text {th }}$ International Pragmatics Conference, vol 2, J. Verschueren (ed.), 396-411. Antwerp: IprA.

Ogden, Richard (2001): "Turn-holding, turn-yielding and laryngeal activity in Finnish talkin-interaction." Journal of the International Phonetic Association 31: 139-152.

Routarinne, Sara 1990. ‘Älkää järkyttykö mut tääl on yks toukka!' Helsinkiläistyttöjen dramaattisia juttuja. Unpublished M.A. thesis, Department of Finnish language, University of Helsinki.

Routarinne, Sara 1997: “Kerrontajäsennys”. In: Keskustelunanalyysin perusteet, Liisa Tainio (ed.), 138-155. Tampere: Vastapaino.

Routarinne, Sara 2003: Tytöt äänessä. Parenteesit ja nouseva sävelkulku kertojan vuorovaikutuskeinoina. [English abstract: Girls talking. Parentheses and rising intonation as narrator's interactional devices.] Helsinki: Finnish Literature Society.

Romaine, Suzanne and Lange, Deborah 1991. "The use of like as a marker of reported speech and thought: a case of grammaticalization in progress. American Speech 66,3: 227-279.

Sacks, Harvey 1974. "An analysis of the course of a joke's telling in conversation.” In: Explorations in ethnography of speaking, Richard Bauman and Joel Sherzer (eds.), 337-353. Cambridge: Cambridge University Press.

Sacks, Harvey 1978. "Some technical considerations of a dirty joke." In: Studies in the organization of conversational interaction, Jim Schenkein (ed.), 249-269. New York: Academic Press.

Sacks, Harvey, Schegloff, Emanuel A. and Jefferson, Gail 1974. "A simplest systematics for the organization of turn-taking for conversation." Language 50: 696-735.

Saussure, Ferdinand de 1983[1916]. Course in general linguistics. London: Duckworth.

Schegloff, Emanuel A. 1979. "The relevance of repair to Syntax-for-Conversation." Syntax \& Semantics 12: 261-286.

Schegloff, Emanuel A. 1990: "On the organization of sequences as a source of "coherence" in talk-in-interaction." In: Conversational organization and its development. Advances in discourse processes 38, B. Dorval (ed.), 51-77. Norwood, NJ: Ablex.

Schegloff, Emanuel A. 1996. "Turn organization: one intersection of grammar and interaction.” In: Interaction and Grammar, Ochs E., Emanuel A. Schegloff and Sandra A. Thompson (eds.), 52-133. Cambridge: CUP.

Schegloff, Emanuel A., Jefferson, Gail and Sacks, Harvey 1977. "The preference for selfcorrection in the organization of repair in conversation." Language 53: 361-382.

Selting, Margret 1996. "On the interplay of syntax and prosody in the constitution of turnconstructional units and turns in conversation." Pragmatics 6,3: 371-388.

Selting, Margret 2001. "Fragments of units as deviant cases of unit production in conversational talk." In: Studies in interactional linguistics, Margret Selting and Elizabeth Couper-Kuhlen (eds.), 229-258. Amsterdam: John Benjamins.

Sorjonen, Marja-Leena 1997: “Korjausjäsennys.” In: Keskustelunanalyysin perusteet, Liisa Tainio (ed.), 111-137. Tampere: Vastapaino.

Sorjonen, Marja-Leena 1999. "Dialogipartikkelien tehtävistä.” Virittäjä 103: 170-194. 
Sorjonen, Marja-Leena 2001a. Responding in Conversation. A study of response particles in Finnish. Amsterdam: John Benjamins.

Sorjonen, Marja-Leena 2001b: "Simple answers to polar questions: The case of Finnish." In: Studies in interactional linguistics, Margret Selting and Elizabeth CouperKuhlen (eds.), 405-431. Amsterdam: John Benjamins.

Sorjonen, Marja-Leena 2002. "Recipient activities. The particle no as a go-ahead response in Finnish conversations." In: The language of turn and sequence, Cecilia E. Ford, Barbara A. Fox and Sandra A. Thompson (eds.), 165-195. New York: Oxford University Press.

Stoltenburg, Benjamin 2003. "Parenthesen im gesprochenen Deutsch." InList 34. http://www.ub.uni-konstanz.de/v13/volltexte/2003/1140//pdf/Inlist34.pdf.

Svennevig, Jan. 1999. Getting Acquinted in Conversation. Amsterdam: John Benjamins.

Terasaki, Alene 1976. "Pre-announcement sequences in conversation." Social Science Working Paper 99. Irvine: University of California.

Tiainen-Duvallon, Outi. 2002. Le pronom anaphorique et l'architecture de l'oral en finnois et en français. Thèse de doctorat non publiée. École Pratique des Hautes Études, Paris.

Vilkuna, Maria 1996. Suomen lauseopin perusteet. Helsinki: Edita.

Vilkuna, Maria 1997. "Into and out of the standard language: The particle $n i$ in Finnish." In: Taming the vernacular: from dialect to written standard language, Jenny Cheshire and Dieter Stein (eds.), 51-67. London and New York: Longman.

Zay, Françoise 1995. "Notes sur l'interprétation des expressions référentielles dans les parenthèses." TRANEL 23: 203-223. 